\title{
TCOM \\ Meat as a matter of fact(s): the role of science in everyday representations of livestock production on social media
}

\section{Ulrika Olausson}

Abstract

Keywords

DOI

Introduction
In recent times we have allegedly witnessed a "post-truth" turn in society. Nonetheless, surveys show that science holds a relatively strong position among lay publics, and case studies suggest that science is part of their online discussions about environmental issues on social media - an important, yet strikingly under-researched, debate forum. Guided by social representation theory, this study aims to contribute knowledge about the role of science in everyday representations of livestock production on social media. The analysis identifies two central themata, namely lay publics' contestations of (1) facts and non-facts, and (2) factual and non-factual sources.

Environmental communication; Public understanding of science and technology; Science and media

https://doi.org/10.22323/2.18060201

Submitted: 20th May 2019

Accepted: 24th September 2019

Published: 29th October 2019

In recent times we have allegedly witnessed a "post-truth" turn in society, i.e. an increased disregard for factual evidence in public discourse [Lockie, 2017]. This turn has been prompted by a combination of the flourishing of (right-wing) populism and the digitization of the media landscape in general and the proliferation of social media in particular [Suiter, 2016]. Furthermore, scholars have argued that this trend of factual rebuttals in favor of emotional appeals is enabled by a general distrust in science resulting from the surge of anti-intellectualism in large parts of the Western world, the politicization of science, and an increasing tendency among ordinary people to critically scrutinize the potential negative consequences of scientific practice [Scheufele, 2013; Takahashi and Tandoc, 2016].

Obviously, even though the emergence of social media might have facilitated its articulation, a discursive-cognitive attribute such as "fact resistance" ${ }^{11}$ is far from new in its essence; there is long-standing empirical evidence that firmly undercuts the "information deficit model," i.e., the idea that if people only had accurate

\footnotetext{
${ }^{1}$ In Swedish: "faktaresistens", which was recognized as a new Swedish word in 2015.
} 
knowledge about the harmful environmental impacts of meat-eating, for example, they would make more pro-environmental food choices [Nisbet and Scheufele, 2009]. Instead, it has been shown that people incorporate such information into the context of their own experiences, worldviews, and identifications, and if it conflicts with their existing beliefs and behaviors, emotional discomfort caused by cognitive dissonance [Kahan, 2006] is likely to arise. A common strategy to reduce dissonance is to reject scientific information, for instance by denying climate change altogether [Olausson, 2011] or by contesting the environmental benefits of various behavioral changes such as reduced meat consumption [Loughnan, Haslam and Bastian, 2010; Olausson, 2018]. However, research also suggests that a particular object might be constituted in profoundly different ways by the same individual, who - in a state of "cognitive polyphasia" - simultaneously holds a multitude of different and context-dependent understandings of this specific reality [Wagner, Duveen et al., 1999]. In this way, individuals might renegotiate representations of scientific (un)certainty in relation to particular messages about, for example, climate change [Rabinovich and Morton, 2012] as well as in various social settings such as the family, place of work, circle of friends, etc. [Olausson, 2011].

It is true that the management of global environmental issues is not only - or even mainly - the responsibility of the individual. As noted by Batel, Castro et al. [2016] (cf. Berglez, Höijer and Olausson [2009] and Olausson and Uggla [2019]), it is vital to acknowledge the structural aspects of environmental degradation, i.e. the responsibility of the $\mathrm{CO}_{2}$ intensive industry, large-scale farming, transport systems, market forces, and other institutional factors, including the responsibility of the political system itself. However, as argued by Beck [2010], this does not rule out the importance of future public support for climate change governance and a "green modernity," where individuals and collectives both make informed pro-environmental decisions in their role as consumers and engage as citizens in moulding public opinion to create pressure on the public institutions.

In sum, as is clearly shown in an extensive research overview by Hornsey et al. [2016], knowledge appears to play a very minor role in people's perceptions of scientific issues in general and of the environment in particular, and confirmation bias seems to be rather the rule than the exception. Nonetheless, and somewhat contradictorily, in a U.S. survey from 2015, 79 percent of the respondents had a positive view of science [Pew, 2015], and previous studies suggest that people, in their online discussions about the environment, make extensive use of scientific knowledge (or at least what is represented as such) [Olausson, 2018; Sharman, 2014]. Thus, on the one hand, there are studies demonstrating that knowledge does not matter much when people make sense of scientific issues, but on the other hand, there are studies indicating the opposite; that science does carry considerable status and that knowledge does have a role to play in sense-making processes. The present study probes more deeply into this ambiguity with a qualitative methodology that builds on social representation theory. This theory is particularly suitable for the exploration of sense-making of abstract phenomena, such as issues that heavily depend on science for their articulation in public discourse [Moscovici, 2000].

\section{Case and aim}

Livestock production for meat and dairy consumption will be used as the case for this study. Despite solid scientific evidence of the multiple harmful effects of a meat 
and dairy based diet, particularly for the environment [Gerber et al., 2013], meat consumption is still on the rise. In Sweden, for instance, where consumption is still low compared with Australia and the U.S.A., there was an increase of 41 percent between 1990 and 2017 (although consumption dropped in 2017 compared to previous years). ${ }^{2}$ Despite the growing body of scientific evidence about meat's environmental impacts, the relationship between meat consumption and environmental degradation was long a non-issue in legacy media in Sweden, as elsewhere [Benulic, 2016]. In 2016, however, there seems to have been an interesting turn of events in this regard, when Swedish climate reporting, besides declining quantitatively, shifted its focus somewhat from dealing with climate change as such to focusing on how meat consumption affects the climate [Vi-Skogen, 2017]. The media's tendency to increasingly acknowledge the link between meat consumption and climate change clearly engaged people in everyday life, not least in social media, and the two most widely shared environmental media items ${ }^{3}$ dealt with livestock production [Vi-Skogen, 2017]. Given the urgent need to reduce meat and dairy consumption for environmental reasons, the recent upswing in public interest in the "meat question" along with its conflict-ridden nature, livestock production constitutes a fruitful case for investigating the role of scientific knowledge in laypeople's sense-making around environmental issues. It should here be understood as an exemplar [Flyvbjerg, 2006], i.e., a critical case which illustrates the more general problem of the various roles science might play in everyday representations of environmental issues, and possibly also other (contested) science-related issues.

It is hardly controversial to claim that the overall media ecology has undergone major shifts in recent years, not least due to the massive expansion of social media such as Facebook, Twitter and Instagram, which are used as sources of information and, not least, as discussion forums. As noted by Hansen [2016], the digitized and interactive media environment implies a notable change in how science-related issues are discursively represented. Network society has fostered a "participatory culture" of "prod-using" and sharing [Jenkins, 2009], which means that representations of environmental issues such as livestock production, for example, are rapidly circulated among large groups of people, who, in turn, might reinforce, negotiate and oppose the representations as communicated on and across the various platforms.

In short, social media constitute an increasingly important forum for public debate and provide a vast data source for studying both previously inaccessible aspects of social interaction and meaning-making, for instance about environmental issues, and emerging ones - shaped by the technological affordances of social media. Thus, the aim of the study is to contribute knowledge about the role of science in everyday representations of livestock production on social media.

\section{Literature review}

With this aim the study addresses an important knowledge gap, identified by Hargittai, Füchslin and Schäfer [2018] (cf. Hutchins [2016]), namely, public

\footnotetext{
${ }^{2}$ http:/ / www.jordbruksverket.se/omjordbruksverket/pressochmedia/nyheter/nyheter2018/ tydligutvecklingviatermindrekottochmersvenskt.5.42a946c0161df8b7b8f1958c.html, retrieved 20 March 2019.

${ }^{3}$ One was an Op-Ed article and the other was a report on that article.
} 
engagement with science in general, and with the environment in particular, through social media. Previous research on laypeople's engagement with and representations of the environment have mostly relied on survey studies [e.g., Poortinga et al., 2011] and focus-group studies [Olausson, 2011; Marcu et al., 2015]. Materials consisting of social media discussions, as in the present study, constitute research data with higher validity because they are unaffected by elements associated with the research process [Olausson, 2018; Regan et al., 2014].

Existing studies focusing on social media in connection with science-related topics have explored communicative networks in relation to various scientific issues [Büchi, 2017], and how various stakeholders make use of social media, for instance, government organizations [Dalrymple, Young and Tully, 2016], academics [Mewburn and Thomson, 2013], and environmental movements [Hestres, 2014; Hutchins, 2016]. Studies have concentrated heavily on the platform Twitter, examples being the role of Twitter in shaping the climate debate [Auer, Zhang and Lee, 2014; Kirilenko and Stepchenkova, 2014], creating open forums as well as echo chambers for climate discussion [Williams et al., 2015], framing IPCC assessment reports [O'Neill et al., 2015], issues pertaining to genetic modification [Wang and Guo, 2018] and nanotechnology [Veltri, 2012]. To a large extent, however, Twitter is associated with elite discourse, and a recent study [Hargittai, Füchslin and Schäfer, 2018], identified Facebook as significantly more attractive for non-specialists when engaging with scientific issues. Consequently, in order to capture the representations of people in everyday life, the present study turns to discussions on the platform Facebook [cf. Olausson, 2018].

The article has four sections including this introduction. The second section accounts for the analytic framework of social representation theory, and introduces the material studied, which consists of Facebook comments on the two most widely shared articles about the environment in 2016. In the third section, the results are structured around the central themata [Marková, 2003] identified in the analysis, namely lay publics' contestations of (1) facts and non-facts, and (2) factual and non-factual sources. It concludes by discussing the rather prominent role that science plays in lay publics' sense-making around environmental issues, the crucial role of science intermediaries, and the role of social media in the (post-)politicization of environmental science.

Theoretical framework, material and method
In order to capture the role of science in everyday representations of livestock production on Facebook, the framework of social representation theory (SRT) was used. Previously, the theory has frequently been used in relation to studies of public understanding of science and technology [e.g. Devine-Wright and Devine-Wright, 2009] and for the investigation of everyday sense-making around various environmental issues [e.g. Olausson, 2011; Marcu et al., 2015]. Research on social representations in this field has however rarely picked up on the unique potential of social media, with its inclusion of a vast array of actors and contexts. The digitized media landscape in general, and social media in particular, offer an unprecedented opportunity to examine the plural character of social representations.

SRT emphasizes collective dimensions of our everyday cognitions of the world that help us organize and familiarize our perceptions [Moscovici, 2000]. The 
relationship between cognition and communication is regarded as a dialectic one; all human communication presupposes social representations at the same time as social representations are maintained, transformed and renewed through communication [Moscovici, 2000]. Social representations should thus be seen both as a product, i.e. a collectively shared mental framework for interpreting, explaining and evaluating events and phenomena, and as a process, i.e. the whole set of meaning-making activities within and between various discursive sites [Moscovici, 1988] among which social media must be regarded as pivotal. The present study focuses in particular on social representations as a process, i.e., on the discursive contests between different ways of representing livestock's environmental impacts, and the role of science in this. As noted by Batel, Castro et al. [2016, p. 733], sense-making is always "relational and co-constructed - and contested, in a community of others." This approach also allows us to go from explaining how the public uses various sense-making tools in the representation of environmental issues to understanding how the public makes sense of and counters other people's conflicting representations [Regan et al., 2014]. As argued by Moscovici [2000, p. 62], "material from samples of conversations gives access to the social representations," and by focusing on social representations as a process rather than a product, the discursive contests over the power to control what representations pass as correct are made visible, something which Hansen [2016] highlights as important to analytically address.

\section{Material and method}

The material ${ }^{4}$ for this study comes from Sweden, a country where environmental issues are comparatively prominent in public discussion and the level of social media use is among the highest in the developed world [Pew, 2016]. Sweden thus constitutes a fruitful case for examining how environmental issues such as livestock production are represented in social media and the role played by science in this.

The material (Table 1) consists of Facebook comments on the two most widely shared media items of 2016 about the environment on Facebook and Twitter [Vi-Skogen, 2017]. ${ }^{5}$ The topical articles — published in the tabloid newspaper Aftonbladet and the magazine Land, and shared on their respective Facebook pages without any further information added to the posts - both defended keeping livestock for meat and dairy production and contrasted it with vacation air travel, which was described as the "real" environmental villain. The two articles thus explicitly downplay the environmental impacts of livestock production. It should be noted that the present study of Facebook comments is not a reception analysis of the original articles. Instead these articles should be understood as a form of stimulus material, as is commonly used in focus-group studies, with an assumed potential to trigger contestation among publics in which scientific knowledge might play a number of different roles.

\footnotetext{
${ }^{4}$ The material was also used in a previous study; see Olausson [2018].

${ }^{5}$ The media analysis reported in Vi-Skogen [2017] was conducted by Retriever, a Swedish company that performs media monitoring and analysis. The report is based on around 150,000 reports in Swedish print and broadcast media (their digital platforms included) during the period 2014-2016. The selected articles garnered 125,411 shares in total on Facebook and Twitter (Land: 77,569 shares; Aftonbladet: 47,842 shares) [Vi-Skogen, 2017, p. 3]. It is noteworthy that among the 100 most frequently shared media items overall, only five dealt with the environment, which could be compared with sports (20 items) and crime (23 items) [Vi-Skogen, 2017, p. 12].
} 
Table 1. Analyzed Facebook comments.

\begin{tabular}{|l|l|l|}
\hline Publication & $\begin{array}{l}\text { Aftonbladet (AB), (online }+ \\
\text { daily tabloid newspaper) }\end{array}$ & $\begin{array}{l}\text { Land (online + weekly } \\
\text { magazine) }\end{array}$ \\
\hline Article headline & $\begin{array}{l}\text { "You blame my cows - and } \\
\text { then take off to Thailand" }\end{array}$ & $\begin{array}{l}\text { "It's not my cows that are the } \\
\text { problem - but your flights to } \\
\text { Thailand" } \text { iii }\end{array}$ \\
\hline Type of article & Op-Ed & Report of the AB Op-Ed \\
\hline $\begin{array}{l}\text { Date of publication } \\
\text { on Facebook }\end{array}$ & 1 Dec 2016 & 3 Jan 2017 ${ }^{\text {iv) }}$ \\
\hline $\begin{array}{l}\text { Number of times } \\
\text { shared }\end{array}$ & 88 & 780 \\
\hline $\begin{array}{l}\text { Number of } \\
\text { Facebook } \\
\text { comments }\end{array}$ & $\begin{array}{l}\text { Original comments: } 76 \\
\text { Comments in threads: } 53 \\
\text { Total: } 129\end{array}$ & $\begin{array}{l}\text { Original comments: } 199 \\
\text { Comments in threads: } 318 \\
\text { Total: } 517\end{array}$ \\
\hline
\end{tabular}

i) According to its editor-in-chief, Land is the only newspaper "with a focus on modern life outside the big cities." http:/ / www.lrfmedia.se/sv / titles/land, retrieved 9 June 2017.

ii) Available at https:/ / www.facebook.com/abdebatt/posts/1761811180749421, retrieved 9 June 2017.

iii) Available at https:/ / www.facebook.com/land/posts/1372909122753420, retrieved 9 June 2017.

iv) This was possibly the second time the article was shared on Land's Facebook page. The first time was not available when the comments were downloaded for analysis.

Broadly speaking, social representations help us organize and familiarize our "ways of world making" [Moscovici, 1988, p. 231], and need to be constituted within familiar domains to take root. In particular, this rings true for sense-making on science-related issues, such as the one under study, which are inherently abstract in character [Moscovici, 2000]. These processes of "familiarization" are captured by SRT's theoretical concepts of anchoring, by which something unfamiliar, such as the environmental impact of livestock production, is brought into a well-known sphere of earlier representations, and objectification, where it is materialized, through a simplified figure or image that correspond to the object, into something concrete that we can perceive [Batel and Devine-Wright, 2015]. The analytical tools, outlined below, build on these concepts. To ensure that the material was systematically analyzed, every comment and every discussion thread were analyzed in order of appearance through the lens of the analytical tools. It should be noted, however, that the Facebook comments are extremely diverse in character, and not every comment dealt with the topic. Such off-topic comments were excluded from the sample in order to avoid analytical irrelevance.

- Dichotomies. According to Marková [2003], to think in antinomies constitutes the very foundation of sense-making, and one important way of transforming that which is unfamiliar into part of a familiar interpretative framework is to organize the construction of meaning around well-known dichotomies, such as good/bad, more/less, etc. [Höijer, 2011]. What dichotomizing strategies of relevance for the role of science in representations of livestock production do the commentators use?

- Metaphors. Metaphors help familiarize new phenomena by transforming them into something more comprehensible, and serve a number of different functions, not least legitimating ones [Höijer, 2011; Wagner and Hayes, 2005]. 
What metaphorical language of relevance for the role of science in representations of livestock production do the commentators use?

- Ontologization. In the process of materialization, the unfamiliar phenomenon is ascribed concrete characteristics - ontologized - so as to make it comprehensible and tangible. Here, the iconic quality of an imprecise idea or object is in focus, and abstract concepts are reproduced in concrete imagery or figures [Moscovici, 2000]. In what ways do the commentators provide their representations of livestock production with concrete characteristics connected to science?

- Emotions. Though not very well elaborated in the original SRT, emotions have been highlighted by Höijer [2011] as important components of social representations. What emotions of relevance for the role of science in representations of livestock production are conveyed in the Facebook discussions?

Together these processes of anchoring and objectification form the more basic themata of social representations [Marková, 2003] — commonly constructed through oppositional categories which prompt contestation [Castro and Gomes, 2005]. The themata, around which the results reported in the next section are structured, were thus inductively identified through the analysis of these anchoring and objectification mechanisms. In order to ensure the transparency of the analytical procedure, i.e., to make visible the connection between analytical tools, the empirical material, and interpretations, the operation of the analytical tools is explicit throughout the analysis [Tracy, 2010].

When it comes to qualitative analysis of social media, there are always ethical issues to take into consideration, such as whether or not to reveal commentators' identities. Since the analyzed comments are published in a public forum, and are searchable on Facebook, it is impossible to guarantee full anonymity. Even so, when reporting the Facebook comments, the initials of the commentators are changed [cf. Olausson, 2018].

\section{Results}

The results section is structured around the central themata identified in the analysis, namely lay publics' contestations of (1) facts and non-facts, i.e., whether information for or against livestock production is reliable and worthy of the label "facts," and (2) factual and non-factual sources, i.e., whether the source of information for or against livestock production is reliable.

\section{Contesting facts and non-facts}

/.../

A.C.:

Well written - I learned a lot, and probably lots of other people did too... Facts are good, so don't have as much "thinking and believing". Really good! 1 Dec. 18.02 . 
A.C.'s comment above is typical of the analyzed Facebook discussions in the sense that "facts" seem to be highly regarded among commentators. However, the analysis shows that, as elements of livestock representations, "science" and "facts" come in many guises; they take very different shapes and serve on the one hand to denounce meat consumption and on the other to justify the very same practice. In short, various understandings of the constitution of reliable facts collide head on in the studied material, depending on what argument they are intended to support.

This discursive contest is exemplified below, where commentator C.A. ontologizes an overall climate-skeptical position - which is evident when s/he rejects human-made climate impacts by representing them as "superstition" — using what seems like advanced statistics. Commentator B.C., in turn, challenges this way of using science, stating that "numbers are good, but it's also important to know what they mean." Both opponents thus ontologize the environmental impacts of livestock production; i.e., they provide them with concrete contours using numbers and what appears to be factual and rather advanced scientific terminology, but with quite different representational outcomes.

\section{C.A.:}

Talking about cow shit and airplane exhaust, in connection with the superstition of climate impact, is indicative of dyslexia and an F in science. Here's what the atmosphere (troposphere) looks like: Nitrogen $(\mathrm{N})=78 \%$, Oxygen $(\mathrm{O})=20.95 \%$, Argon $(\mathrm{Ar})=0.95 \%$, Carbon Dioxide $(\mathrm{CO} 2)=0.04 \%$, Neon $(\mathrm{Ne})=0.002 \%$ and the rest noble gases incl. hydrogen $=0.00086 \%$. The cow shit fits into that $0.00086 \%$. Within that $0.004 \%$ are a few thousandths of a promille emissions from air travel, get a grip or use your goddamn brains! 4 Jan. 14.43 .

B.C.:

Numbers are good, but it's also important to know what they mean. As we know, the warming of the atmosphere is caused by certain gases preventing heat from radiating out into space, by absorbing infrared radiation. The greenhouse gas with the greatest effect is carbon dioxide, it's only $4 \mathrm{ppm}$ in the atmosphere but has a large effect anyway. And the proportion is $40 \%$ higher than before industrialism took off. The problem with methane in particular is that it's a very powerful greenhouse gas, about 72 times stronger than $\mathrm{CO} 2$, if I remember right. / ... / I think it's unfair (and to be honest a bit childish) to claim that people who draw other conclusions than you do don't understand science. 4 Jan. 18.09
/.../
Land

As shown above, for instance when C.A. urges readers to "use your goddamn brains," the seemingly advanced scientific terminology is combined with and underscored by expressions of frustration and even anger, which set the foundation for ad hominem arguments, where discussants attack the other person rather than his/her argument. As also demonstrated by previous research, mudslinging or incivility is a significant discursive strategy in discussions on environmental issues (and not least the meat issue) in social media, notwithstanding the overall efforts among commentators to build ethos through scientific language [Anderson and Huntington, 2017; Olausson, 2018]. 
In this way, science is represented in largely conflicting ways to strengthen each opponent's own point of view through ontologization in different statistical numbers and figures, and emotional expressions in the form of frustration, contempt or aggression supports the position. Additionally, as part of the latter discursive strategy, commentators stress the significance of (scientific) knowledge by engaging in mutual accusations of "ignorance" and being "uneducated." Such accusations are deployed by both parties to dismiss each other's arguments. The first quotation below exemplifies how this is done in order to counter arguments that deny meat's environmental impacts, and the second exemplifies how it is done with the opposite purpose.

\section{D.E.:}

So much ignorance. Sure, flying is bad for the environment, but the ENTIRE global meat industry is the main villain. It's time to bring in some knowledge, I grew up as a farm girl and would normally defend the meat industry but truth be told it's the meat industry that's the villain in the drama... Oil, air travel and the meat industry, they're all contributing factors to the greenhouse effect 4 Jan. 13.10.

/.../

Land

E.F.:

Sure, grass makes cows fart. and the methane is later oxidized in the atmosphere into $\mathrm{CO} 2$ and water. The alternative without cows is that the same grass rots and turns into $\mathrm{CO} 2$ and water in the atmosphere. Swedish media and journalists have zero idea how nature works in general, and like children can only focus on a little piece of nature at a time, such as a cow's anus. 1 Dec. 15.47 .

$A B$

As the last quotation indicates, it seems as if the "elite" - here embodied as Swedish journalists - is a main target of accusations of ignorance or lack of knowledge, at least when it comes to representations that justify livestock production and deny its environmental impacts. In the quotations below, not only journalists but also politicians and the environmental movement, pejoratively and metaphorically labeled "environment freaks" in the second quote, are accused of spreading "incorrect facts," as expressed by E.D., and of being impervious to "the real facts," as F.A. states.

\section{E.D.:}

It's tragic that journalists and politicians always present incorrect facts about everything to do with environmental impacts. Get facts before opening your mouths. It's strange that the different newsdesks don't set higher standards. If these journalists could be fired for the errors they trumpet out then maybe things would change. /.../4 Jan. 15.39.

Land

F.A.:

Yes, journalists and environment freaks aren't receptive to the real facts. /.../. It's not the cows, not the cars, not air travel that's the villain, but the boats. When one boat emits more carbon dioxide than 50 million cars. So what are 
the environment freaks here in Sweden talking about? Through their hats. /.../ 1 Dec. 16.39.

$A B$

While it is true that similar discursive strategies are used by both parties to reject the other's argument, i.e., to make the environmental impacts of livestock production tangible by ontologizing them in the form of what appear to be scientific facts, it is also the case that seemingly science-based arguments are countered with strategies that have nothing whatsoever to do with scientific knowledge. This is demonstrated in the exchange involving several commentators below, where E.F. introduces the thread by using scientific language when arguing that livestock production is environmentally harmful, while G.O. counters this argument not with similar discursive strategies, but with emotional expressions of contempt or scorn, blaming E.F. for being "gullible," while simultaneously implying an underlying conspiracy, namely that powerful forces in society are attempting to deceive the public into believing in the environmental impacts of meat consumption.

\section{E.F.:}

Beef generates total emissions corresponding to around $26 \mathrm{~kg}$ of carbon dioxide per $\mathrm{kg}$ of meat, chicken around $3 \mathrm{~kg}$, and grains and legumes around $0.5 \mathrm{~kg}$ per $\mathrm{kg}$ of prepared product. Try again and get it right this time Your cows can beneficially be traded for chickens......3 Jan. 14:37.

/.../

G.O.:

Yeah, you're probably one of those gullible people we could really use fewer of in this country, how's your shopping going? 3 Jan. 15:09

The ongoing discursive contest about the relationship between livestock and environmental devastation also encompasses discursive strategies of dichotomization. The exchange below exemplifies how livestock's environmental harm is firmly anchored in the familiar and oppositional categories of facts, i.e. scientifically verified information, and opinions, i.e. ideas that are not supported by documented knowledge.

$/ \ldots /$

G.F.:

If Sweden could refuse to import meat containing too much antibiotics then I think we can keep eating meat. Personally I'd rather eat meat than soy burgers, because I think the production of soy wears down the environment more than all the cows do. /... / 3 Jan. 20.22.

H.G.:

You can't "think" that soybean production contributes to greater environmental impact. It's facts that you ought to present when making an argument about environmental impacts. Do you know why soybeans "wear down" the environment? Do you know why we produce such large amounts of soybeans? They're an awesome source of protein in animal feed. These animals in turn are lying on our plates. /.../3 Jan. 21.20.

/.../

Land 
The exchange below starts with commentator J.V., who points to livestock's environmental impacts by referring to certain (scientific) information. S.A., in turn, responds by dismissing this information and accusing J.V. of lacking knowledge - an accusation that tends to appear together with discursive strategies of emotions, as also shown above.

J.V.:

A "biased" dairy farmer who argues for milk and her exploitation of cows by smearing something else. Two wrongs don't make a right. Also, she only talks about methane, which is one of the problems, but avoids mentioning the energy inefficiency of producing meat and milk. The transports that it involves. The incredible amounts of water that are needed, etc., etc.../.../. 1 Dec. 14.24 .

/.../

\section{S.A.:}

The studies about the unbelievable water consumption are so completely wrong that they are out of this world. But once incorrect information has gone viral it becomes truth. Find out what's correct next time. 1 Dec. 21.41.

The dichotomization between facts and opinion becomes evident at a later stage of this discussion, which at this point involves several commentators, J.V. discards the information put forward by pejoratively labeling it "opinions," and points instead to "accepted facts." S.A., in turn, metaphorically refers to a "water footprint balloon" when responding to J.V. in order to strengthen the representation that livestock production is environmentally harmless.

/.../

J.V.:

/... / Well it's not about opinions but about accepted facts. The UN agriculture organization, WHO, the Swedish Environmental Protection Agency and other "viral" sources. /.../ 2 Dec. 09.23.

/.../

S.A.:

J.V. look at the following blog article which pretty easily pokes a hole in your water footprint balloon http:/ /blogg.land.se/.../kottproduktionens... / 2 Dec. 11.46.

/.../

J.V.:

S., So your source is a blog by a meat producing farmer rather than the UN, the Environmental Protection Agency, etc. 2 Dec. 12.29.

$A B$

As the discursive contest between S.A. and J.V. unfolds, it becomes increasingly clear that in order to distinguish between facts and opinions, commentators struggle to assess the reliability of the information sources. This will be further developed in the next section. 
In sum, the themata of the Facebook discussions analyzed above is a dichotomized categorization of facts vs. non-facts, either in the ontologization of livestock production by seemingly advanced but nonetheless conflicting statistics and numbers, or by contrasting facts and opinions. Ontologization strategies, such as using scientific numbers when concretizing the environmental impacts of livestock, intermingle with other anchoring and objectification strategies such as metaphorical language and emotional expressions of frustration and scorn in order to de-legitimize the opponent's viewpoint.

\section{Contesting factual and non-factual sources}

When Facebook commentators aspire to ontologize the issue of livestock production in what is represented as scientific information, the discursive contest not only revolves around the themata of facts and non-facts, but also concerns factual and non-factual sources. This call for accountability and transparency is illustrated in the quotation below, where L.I. urges V.O. - who deploys the well-established dichotomy of nature (livestock) and culture (technology), when arguing that livestock is not a cause of climate change - to verify this position.

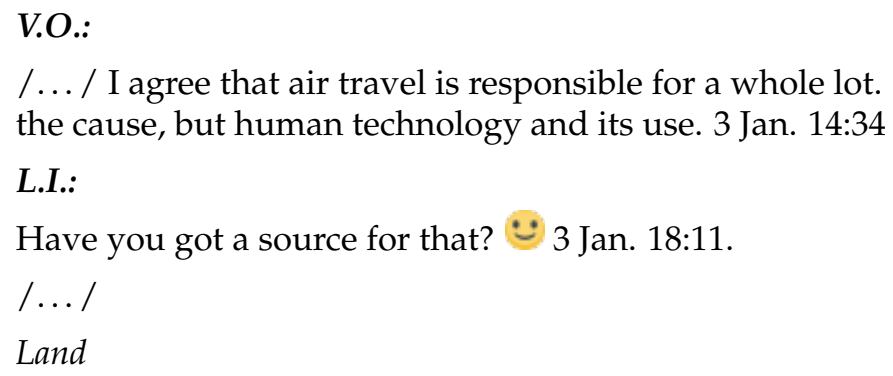

Below, commentator A.P. starts the thread by complaining about "the low level of knowledge" in the Facebook comments and attempts to avoid similar accusations by providing a link to a study in Science that verifies the environmental impacts of methane. However, G.N. questions the accuracy of this conclusion by contesting the source, and finally rejects it completely when $\mathrm{s} /$ he ontologizes the abstract phenomenon of methane as mere "cow farts" and, in this way, discursively plays down its alleged severity. In the exchange below emotional expressions of disdain is discernible through the repetitive, ironic use of "my dear".

\section{A.P.:}

I don't know which is more embarrassing, the low level of knowledge revealed in some of the comments or the fact that Aftonbladet chose to publish the article. Methane has between 20 and 35 times greater environmental impact that carbon dioxide, kilo by kilo. The debate article is a partisan opinion piece. /... / https:/ /www.google.co.uk/... /sve... /sida/amp/article/3203049 1 Dec. 17.49 .

\section{G.N.:}

And how do you know there's any truth in the article that you link to? 1 Dec. 17.49 . 
A.P.:

Well, my dear G. I'm not a climate scientist myself so I simply have to trust that Science, one of the largest scientific journals in the world, has a system for ensuring that the research they publish is scientifically supported. 1 Dec. 17.54.

\section{G.N.:}

Well, my dear A. In that case I'll listen to the researchers who say that Swedish cow farts aren't the cause of climate change and assume they have no reason to lie. 1 Dec. 19.44 .

$/ \ldots /$

$A B$

To reject the other's sources as non-factual and thus unreliable is apparently a powerful way to deny the environmental impacts of livestock production. In the thread below E.M. counters previous accusations that the documentary Cowspiracy is an unreliable source by conveying emotions of frustration; critical commentators "ought to realize" that they should provide other sources themselves. K.M. in turn continue the argumentation against Cowspiracy by dichotomizing between veganism - of which Cowspiracy is seen as a propaganda instrument - and the matter of facts.

\section{E.M.:}

S., L., and R., all the sources for Cowspiracy are available on their website. If you have something against the academic sources, well, then you ought to realize you need to present more correct sources yourself. 1 Dec. 19.48.

\section{K.M.:}

Cowspiracy is propaganda for veganism. And has many fake sources. Absolutely untrue. 2 Dec. 00.09.

$A B$

In a similar manner, NGO sources such as the Swedish Society for Nature Conservation (SSNC) ${ }^{6}$ or the World Wide Fund for Nature (WWF) are dismissed by critical commentators when they are cited as sources in support of the argument that meat causes environmental harm. In the quotation below, B.K. represents the assumed biased nature of the former by metaphorically comparing it with "SD," i.e. the right-wing party Sweden Democrats.

I.I.:

http:/ / m.naturskyddsforeningen.se/vad-vi-gor/klimat/faqvego Apples, oranges, cows, airplanes, methane, carbon dioxide. The comparisons here are many but the more we know the better choices we make! Eat less meat is how I see it anyway...\&. 1 Dec. 09.18.

\section{B.K.:}

Looking for answers from the Society for Nature Conservation, is like asking SD to give their opinion on immigration, biased and pure lies. 1 Dec. 09.22.

/.../

$A B$

\footnotetext{
${ }^{6}$ In Swedish: Naturskyddsföreningen.
} 
In sum, the themata of factual and non-factual sources takes shape among both parties in the discursive struggle over the power to define the meat issue. This themata implies that people who are actively discussing science-related issues on social media, as studied here, are far from ignorant about the difficulty of navigating among and discriminating between the plethora of scientific results and other types of online information. There is, however, no consensus about how to assess the quality of the various sources, and this is instead used as a weapon when struggling over what representations of livestock production pass as correct.

Discussion and conclusions
The analysis presented here suggests that scientific knowledge does play a prominent role in lay publics' sense-making around environmental issues, notwithstanding the post-truth turn, the surge of anti-intellectualism, and the politicization of science discussed in the introduction of this article. Thus, science and knowledge are neither straight-forwardly "resisted" (as in fact resistance) nor simply rebutted (as in post-truth), but are used in numerous diverging ways as weapons in the struggle for power over issue definition.

Within the collective of FB-commentators, the co-existence of meanings - or "cognitive polyphasia" - is evident when common-sensical notions of traditional (meat-)eating habits encounter new ideas of reduced meat-consumption, and scientific language is used by both parties in the discursive contest over how to assess the environmental impacts of livestock. Thus, it is vital to acknowledge that public understanding of science might not always represent accurate interpretations of scientific results, but the point to be emphasized here, is that science as a phenomenon still seems to hold considerable prestige among lay publics.

This means that the problem that science communicators, for example, face might not have to do with a lack of trust in science as much as with a lack of trust in other institutions and intermediaries [Schäfer, 2016]. As shown in the analysis, representations of livestock production and its environmental impacts intermingle with fake-news discourse and distrust in traditional news media [cf. Olausson, 2018; Regan et al., 2014]. As one of the most important intermediaries [Schäfer, 2016], the media are the ones making science accessible to the public and selecting which scientific results to highlight. When people trust the media and the scientists quoted in the press, they use that trust as a heuristic to believe the information presented [Brewer and Ley, 2013; Takahashi and Tandoc, 2016]. However, when people lose confidence in legacy media and more or less regard it as a propaganda instrument for various special interests, a similar process of distrust by association takes root, which in turn paves the way for the multitude of alternative sources online.

Thus, the obstacles that scientists, science communicators, journalists, and policy makers are currently facing when communicating environmental issues can only partially be overcome by improving (science) communication alone. The results make it quite clear that sense-making is to a significant extent influenced by underlying structural mechanisms, such as the influence of right-wing populist discourse with its inherent distrust in traditional institutions, not least politics and the media, as well as in the environmental movement. As argued by Uzzell and Räthzel [2009] (cf. Batel, Castro et al. [2016]), there is a need to shift attention from the individual to the social and political contexts, where values and behaviors related to the environment are shaped. Consequently, future research on everyday 
representations of science-related issues should attempt to de-cloak the most "basic," "primary,", or "pre-existing" themata that operate on the structural level of discourse and "never reveal themselves clearly" [Moscovici, 2000, p. 182], but nonetheless are constitutive of sense-making processes.

Finally, when reading Facebook commentators' discussions about environmental issues, one easily gets uncomfortable with the rude tone and overall incivility. Another way to look at these "social-media frays" is to acknowledge the potential of these platforms to actually counter the post-politicization of the environment. According to several scholars [Maeseele and Raeijmaekers, 2017], environmental discourses in general, and climate change discourse in particular, have entered the post-political stage through a consensual public discourse, lacking the agonistic element which, according to Mouffe [2005], is constitutive of a well-functioning democracy. Climate conflicts seem to have shifted - at least in part - from direct denial of human-made climate change to rejection of the science behind various causes and solutions [Schmid-Petri et al., 2017] such as meat production and consumption as in the topical case. As argued by Höijer [2011] (cf. Batel and Devine-Wright [2015]), everyday thinking/discourse is multidimensional and characterized by cognitive polyphasia, which means that it is quite possible for people to agree with scientific claims on a general and/or normative level (e.g. climate change) but disagree with them when they intervene in their everyday lives (e.g. reduced meat consumption). Obviously, the indications that the affordances of social media actually help co-existing meanings surface discursively, suggested by the present study, need further empirical verification and critical examination.

\section{References}

Anderson, A. A. and Huntington, H. E. (2017). 'Social media, science and attack discourse: how Twitter discussions of climate change use sarcasm and incivility'. Science Communication 39 (5), pp. 598-620. https://doi.org/10.1177/1075547017735113.

Auer, M. R., Zhang, Y. and Lee, P. (2014). 'The potential of microblogs for the study of public perceptions of climate change'. Wiley Interdisciplinary Reviews: Climate Change 5 (3), pp. 291-296. https://doi.org/10.1002/wcc. 273.

Batel, S., Castro, P., Devine-Wright, P. and Howarth, C. (2016). 'Developing a critical agenda to understand pro-environmental actions: contributions from Social Representations and Social Practices Theories'. Wiley Interdisciplinary Reviews: Climate Change 7 (5), pp. 727-745. https://doi .org/10.1002/wcc . 417.

Batel, S. and Devine-Wright, P. (2015). 'Towards a better understanding of people's responses to renewable energy technologies: insights from Social Representations Theory'. Public Understanding of Science 24 (3), pp. 311-325. https://doi.org/10.1177/0963662513514165.

Beck, U. (2010). 'Climate for change, or how to create a green modernity?' Theory, Culture $\mathcal{E}$ Society 27 (2-3), pp. 254-266. https://doi.org/10.1177/0263276409358729.

Benulic, K.-S. (2016). 'A beef with meat: media and audience framings of environmentally unsustainable production and consumption'. Dissertation. Huddinge, Sweden: Södertörns högskola. 
Berglez, P., Höijer, B. and Olausson, U. (2009). ‘Nationalisation and individualisation of the climate issue: two ideological horizons in Swedish news media'. In: Climate change and the media. Ed. by T. Boyce and J. Lewis. New York, NY, U.S.A.: Peter Lang, pp. 211-223.

Brewer, P. R. and Ley, B. L. (2013). 'Whose Science Do You Believe? Explaining Trust in Sources of Scientific Information About the Environment'. Science Communication 35 (1), pp. 115-137. https://doi.org/10.1177/1075547012441691.

Büchi, M. (2017). 'Microblogging as an extension of science reporting'. Public Understanding of Science 26 (8), pp. 953-968. https://doi.org/10.1177/0963662516657794.

Castro, P. and Gomes, I. (2005). 'Genetically modified organisms in the Portuguese press: thematization and anchoring'. Journal for the Theory of Social Behaviour 35 (1), pp. 1-17. https://doi.org/10.1111/j.0021-8308.2005.00261.x.

Dalrymple, K. E., Young, R. and Tully, M. (2016). "'Facts, not fear": negotiating uncertainty on social media during the 2014 Ebola crisis'. Science Communication 38 (4), pp. 442-467. https : //doi .org/10.1177/1075547016655546.

Devine-Wright, H. and Devine-Wright, P. (2009). 'Social representations of electricity network technologies: exploring processes of anchoring and objectification through the use of visual research methods'. British Journal of Social Psychology 48 (2), pp. 357-373. https://doi.org/10.1348/014466608x349504.

Flyvbjerg, B. (2006). 'Five misunderstandings about case-study research'. Qualitative Inquiry 12 (2), pp. 219-245. https://doi .org/10.1177/1077800405284363.

Gerber, P. J., Steinfeld, H., Henderson, B., Mottet, A., Opio, C., Dijkman, J., Falcucci, A. and Tempio, G. (2013). Tackling climate change through livestock - a global assessment of emissions and mitigation opportunities. Rome, Italy: Food and Agriculture Organization of the United Nations.

Hansen, A. (2016). 'The changing uses of accuracy in science communication'. Public Understanding of Science 25 (7), pp. 760-774. https://doi.org/10.1177/0963662516636303.

Hargittai, E., Füchslin, T. and Schäfer, M. S. (2018). ‘How do young adults engage with science and research on social media? Some preliminary findings and an agenda for future research'. Social Media + Society 4 (3), pp. 1-10. https://doi.org/10.1177/2056305118797720.

Hestres, L. E. (2014). 'Preaching to the choir: Internet-mediated advocacy, issue public mobilization and climate change'. New Media $\mathcal{E}$ Society 16 (2), pp. 323-339. https://doi.org/10.1177/1461444813480361.

Höijer, B. (2011). 'Social representation theory: a new theory for media research'. Nordicom Review 32 (2), pp. 3-16. https://doi .org/10.1515/nor-2017-0109.

Hornsey, M. J., Harris, E. A., Bain, P. G. and Fielding, K. S. (2016). 'Meta-analyses of the determinants and outcomes of belief in climate change'. Nature Climate Change 6 (6), pp. 622-626. https://doi.org/10.1038/nclimate2943.

Hutchins, B. (2016). 'The many modalities of social networking: the role of Twitter in greens politics'. Environmental Communication 10 (1), pp. 25-42. https://doi.org/10.1080/17524032.2014.966853.

Jenkins, H. (2009). Confronting the challenges of participatory culture. Cambridge, U.K.: The MIT Press. 
Kahan, D. M. (2006). 'Cultural cognition and public policy'. Yale Law \& Policy Review 24, p. 147. URL: http://digitalcommons. law.yale.edu/fss_papers/103.

Kirilenko, A. P. and Stepchenkova, S. O. (2014). 'Public microblogging on climate change: One year of Twitter worldwide'. Global Environmental Change 26, pp. 171-182. https://doi.org/10.1016/j.gloenvcha.2014.02.008.

Lockie, S. (2017). 'Post-truth politics and the social sciences'. Environmental Sociology 3 (1), pp. 1-5. https: //doi .org/10.1080/23251042.2016.1273444.

Loughnan, S., Haslam, N. and Bastian, B. (2010). 'The role of meat consumption in the denial of moral status and mind to meat animals'. Appetite 55 (1), pp. 156-159. https://doi.org/10.1016/j.appet.2010.05.043.

Maeseele, P. and Raeijmaekers, D. (2017). 'Journalism and democracy: towards a sustainable future'. In: What is sustainable journalism? Integrating the environmental, social and economic challenges of journalism. Ed. by P. Berglez, U. Olausson and M. Ots. New York, NY, U.S.A.: Peter Lang, pp. 116-134. https://doi.org/10.3726/b11462.

Marcu, A., Gaspar, R., Rutsaert, P., Seibt, B., Fletcher, D., Verbeke, W. and Barnett, J. (2015). 'Analogies, metaphors and wondering about the future: lay sense-making around synthetic meat'. Public Understanding of Science 24 (5), pp. 547-562. https://doi.org/10.1177/0963662514521106.

Marková, I. (2003). Dialogicality and social representations: the dynamics of mind. Cambridge, U.K.: Cambridge University Press.

Mewburn, I. and Thomson, P. (2013). 'Why do academics blog? An analysis of audiences, purposes and challenges'. Studies in Higher Education 38 (8), pp. 1105-1119. https://doi.org/10.1080/03075079.2013.835624.

Moscovici, S. (2000). Social Representations: Explorations in Social Psychology. Cambridge, U.K.: Polity Press.

Moscovici, S. (1988). 'Notes towards a description of Social Representations'. European Journal of Social Psychology 18 (3), pp. 211-250. https://doi.org/10.1002/ejsp.2420180303.

Mouffe, C. (2005). On the political. New York, NY, U.S.A.: Routledge.

Nisbet, M. C. and Scheufele, D. A. (2009). 'What's next for science communication? Promising directions and lingering distractions'. American Journal of Botany 96 (10), pp. 1767-1778. https://doi.org/10.3732/ajb.0900041.

O'Neill, S., Williams, H. T. P., Kurz, T., Wiersma, B. and Boykoff, M. (2015). 'Dominant frames in legacy and social media coverage of the IPCC Fifth Assessment Report'. Nature Climate Change 5 (4), pp. 380-385. https://doi.org/10.1038/nclimate2535.

Olausson, U. (2011). "“We're the ones to blame": citizens' representations of climate change and the role of the media'. Environmental Communication 5 (3), pp. 281-299. https://doi.org/10.1080/17524032.2011.585026.

- (2018). "'Stop blaming the cows!": how livestock production is legitimized in everyday discourse on Facebook'. Environmental Communication 12 (1), pp. 28-43. https://doi.org/10.1080/17524032.2017.1406385.

Olausson, U. and Uggla, Y. (2019). 'Celebrities celebrifying nature: the discursive construction of the human-nature relationship in the 'Nature is speaking' campaign'. Celebrity Studies, pp. 1-18. https://doi.org/10.1080/19392397.2019.1626749. 
Pew (2015). Public and scientists' views on science and society.

URL: http://www . pewinternet.org/2015/01/29/public-and-scientists-vie ws-on-science-and-society/ (visited on 30th October 2018).

- (2016). Spring 2016 global attitudes survey. URL: http://www . pewresearch.org/fact-tank/2017/04/20/not-everyone-in -advanced-economies-is-using-social-media/ (visited on 18th September 2017).

Poortinga, W., Spence, A., Whitmarsh, L., Capstick, S. and Pidgeon, N. F. (2011). 'Uncertain climate: An investigation into public scepticism about anthropogenic climate change'. Global Environmental Change 21 (3), pp. 1015-1024. https://doi.org/10.1016/j.gloenvcha.2011.03.001.

Rabinovich, A. and Morton, T. A. (2012). 'Unquestioned answers or unanswered questions: beliefs about science guide responses to uncertainty in climate change risk communication'. Risk Analysis 32 (6), pp. 992-1002. https://doi.org/10.1111/j.1539-6924.2012.01771.x.

Regan, Á., Shan, L., McConnon, Á., Marcu, A., Raats, M., Wall, P. and Barnett, J. (2014). 'Strategies for dismissing dietary risks: insights from user-generated comments online'. Health, Risk \& Society 16 (4), pp. 308-322. https://doi.org/10.1080/13698575.2014.919993.

Schäfer, M. S. (2016). 'Mediated trust in science: concept, measurement and perspectives for science communication'. JCOM 15 (05), C02. URL: http://jcom.sissa.it/archive/15/05/JCOM_1505_2016_C02.

Scheufele, D. A. (2013). 'Communicating science in social settings'. Proceedings of the National Academy of Sciences 110 (Supplement 3), pp. 14040-14047. https://doi.org/10.1073/pnas.1213275110.

Schmid-Petri, H., Adam, S., Schmucki, I. and Häussler, T. (2017). 'A changing climate of skepticism: the factors shaping climate change coverage in the U.S. press'. Public Understanding of Science 26 (4), pp. 498-513. https://doi.org/10.1177/0963662515612276.

Sharman, A. (2014). 'Mapping the climate sceptical blogosphere'. Global Environmental Change 26, pp. 159-170. https://doi.org/10.1016/j.gloenvcha.2014.03.003.

Vi-Skogen (2017). Varmare klimat — iskall nyhet. [Warmer climate - ice cold news]. URL: https://viskogen.se/nyhet/ny-rapport-klimatskeptikerna-gor-come back/.

Suiter, J. (2016). 'Post-truth politics'. Political Insight 7 (3), pp. 25-27. https://doi.org/10.1177/2041905816680417.

Takahashi, B. and Tandoc, E. C. J. (2016). 'Media sources, credibility, and perceptions of science: Learning about how people learn about science'. Public Understanding of Science 25 (6), pp. 674-690. https://doi.org/10.1177/0963662515574986.

Tracy, S. J. (2010). 'Qualitative quality: eight "big-tent” criteria for excellent qualitative research'. Qualitative Inquiry 16 (10), pp. 837-851. https://doi.org/10.1177/1077800410383121.

Uzzell, D. and Räthzel, N. (2009). 'Transforming environmental psychology'. Journal of Environmental Psychology 29 (3), pp. 340-350. https://doi.org/10.1016/j.jenvp.2008.11.005. 
Veltri, G. A. (2012). 'Microblogging and nanotweets: nanotechnology on Twitter'. Public Understanding of Science 22 (7), pp. 832-849. https://doi.org/10.1177/0963662512463510.

Wagner, W. and Hayes, N. (2005). Everyday discourse and common sense: the theory of social representation. Basingstoke, U.K.: Palgrave Macmillan.

Wagner, W., Duveen, G., Themel, M. and Verma, J. (1999). 'The modernization of tradition: thinking about madness in Patna, India'. Culture \& Psychology 5 (4), pp. 413-445. https://doi.org/10.1177/1354067x9954003.

Wang, W. and Guo, L. (2018). 'Framing genetically modified mosquitoes in the online news and Twitter: intermedia frame setting in the issue-attention cycle'. Public Understanding of Science 27 (8), pp. 937-951. https://doi.org/10.1177/0963662518799564.

Williams, H. T. P., McMurray, J. R., Kurz, T. and Hugo Lambert, F. (2015). ‘Network analysis reveals open forums and echo chambers in social media discussions of climate change'. Global Environmental Change 32, pp. 126-138. https://doi.org/10.1016/j.gloenvcha.2015.03.006.

Author

Ulrika Olausson is Professor of Media and Communication Studies at Jönköping University, Sweden. Her research expertise includes environmental and science communication in relation to journalism, social media, and the public.

E-mail: ulrika.olausson@ju.se.

\section{How to cite}

Olausson, U. (2019). 'Meat as a matter of fact(s): the role of science in everyday representations of livestock production on social media'. JCOM 18 (06), A01. https://doi.org/10.22323/2.18060201. 